\title{
Taxation: A Delicately Planned Arrangement of Cargo
}

\author{
James E. Sabine*
}

[One of the problems of the expansion of governmental functions is] ... distributing the burden of taxation equitably among taxpayers according to their ability to pay. The revenue laws must be as delicately planned as the arrangement of cargo for the hold of a ship if they are to equilibrate the incidence of a variety of taxes.... $\dagger$

No one has Contributed as mucl to the tax system of California as 1 Chief Justice Roger J. Traynor. This system is a monument to his creative talents and industry. His contribution is not just that of a theorist; he has been on the front line in the areas of legislation, tax administration, and the case-by-case evolution of tax law in the courts.

I

\section{THE EARLY DAYS}

Chief Justice Traynor's career in taxation in large part accounts for the establishment of a revenue system that soon gained recognition as one of the finest in the country. While in his early thirties, le figured prominently in the drafting of the statutes that still serve to provide the principal state revenues. The tax systen of which he was the chief architect lias stood the stress of state government for over thirty years, during which time the state population has expanded from some five and a lalf million to over eighteen million and the revenue from state taxes has increased from less than $100,000,000$ dollars $^{1}$ to over $2,800,000,000$ dollars $^{2}$ a year. There have been few significant additions to the California tax system since Chief Justice Traynor drafted the principal statutes. The State of California reaps endlessly the benefits of his labors.

Chief Justice Traynor's interest in taxation was sparked by Morley's Life of Gladstone. As a then young graduate student simultaneously engaged in earning his Ph.D. in political science and his law degree at the University of California, he pondered Gladstone's comment that a sound revenue system is indispensable to sound government. Young Traynor brought his own reflection to bear upon that comment across

\footnotetext{
* Assistant Attorney General of California; Visiting Lecturer in Law, University of California, Berkeley.

†Traynor \& Surrey, New Roads Toward the Settlement of Federal Income, Estate and Gift Tax Controversies, 7 Law \& Contearp. Prob. 336 (1940).

1 Report of Cal. Tax Research Bureau 182 (1933).

2 Cal. Controlier Ann. Rep. A-16 (1964).
} 
busy days consumed with teaching and writing. His reflection culminated in a small classic, as original in analysis as it was painstaking in documentation, entitled "National Bank Taxation in California."

In 1930 he established one of the pioneer law school courses in taxation at a time when such courses were unheard of in the curricula of most law schools. ${ }^{4} \mathrm{He}$ was an inspiring teacher. During the decade in which he taught taxation, he so successfully conveyed the intellectual excitement and challenge in the world of taxation that he set the careers of many of his students.

Fortuitously Chief Justice Traynor's emergence as a tax expert came at a time when his services were most needed, during the depression years. In that desperate time the state's financial needs far outran the revenues available under a wholly inadequate tax system. In a report submitted January 16, 1933, the State Board of Equalization advised the Governor the state was "confronted with a tax crisis," and that "what may be done to meet this crisis is, in our judgment, the most vital problem confronting the people of California and their legislative representatives today. . . ." Public interest in state tax problems in the early nineteenthirties is reflected in a comment of the State Board of Equalization in 1935 that " tax problems have had inore public attention in California during the past two years than in any previous biennial period since the State Board of Equatization was establislied in 1879.186

The legislature had, in 1931, created a Tax Research Bureau "to make a full and complete investigation of the actual operation of the systems of revenue, taxation and public finance" and to report its recommendations to the Legislature. One of the nation's ablest tax administrators, the late Dixwell L. Pierce, who served for thirty-seven years as Secretary of the California State Board of Equalization, successfully sought the services of the rising young professor of taxation to serve as Legal Counsel to the Tax Research Bureau. These two men of gentle temperament, dedicated to just as well as efficient tax administration, became effective colleagues in the never-ending tasks that beset them.

In the course of his new responsibilities in Sacramento, superimposed upon his teaching at Boalt Hall, Traynor undertook a critical study of the Bank and Corporation Franchise Tax Act, as it read in 1931, setting forth proposed changes and the reasons therefor. This analysis served; in part, as a basis for recommendations made by the Bureau to the legislature. He also wrote a comprehensive one-hundred page chapter

317 Casf. L. REv. 83, 232, 456 (1929).

4 Traynor, Tax Laws Deserve Sound Administration, Proceedrags of Forty-Nintre AnNoal Conference of the Nationar TaX Association 44 (1956).

5 Report of California State Board of Equalization for 1931-1932, 9 (1933).

6 Report of California State Board of Equalization for 1933-1934, 9 (1935). 
on the Bank and Corporation Franchise Tax Act for the 1932 edition of Ballantine's California Corporation Lawe. ${ }^{7}$

The report of the Bureau was submitted to the legislature on January $23,1933,8$ and it prompted the enactment during the next four years of a comprehensive program of state taxation that has survived across the years with little change. In 1933 there was a complete revision of the Bank and Corporation Franchise Tax Act with the most significant changes being made in the method of taxing national banks. As principal draftsman of the revised tax on banks, Traynor ingeniously solved the problem of equalizing the taxation of banks and non-financial corporations in a manner consistent with the federal statute authorizing state taxation of national banks. ${ }^{9}$ The solution was to tax banks under the Bank and Corporation Franchise Tax Act at the same basic percentage of net income as other corporations, but also to impose an additional percentage on banks equivalent to the percentage of net income that other.corporations were required to pay as personal property taxes, from which national banks were exempt under federal law. ${ }^{10}$

The California method has been recognized as a fair solution of the problem, ${ }^{11}$ and extended litigation contesting the validity of the California method of taxing national banks ended in vindication of the tax. Upholding its validity, in Security-First National Bank v. Franchise Tax Board, ${ }^{12}$ the Supreme Court of Califorma stated: "Section $4 \mathrm{a}$ is designed to impose on banks a fair and equitable tax within the restrictions of section 5219, and the lack of any discrimination against banks is clear when the entire tax burden of other corporations is taken into consideration. . . ."1s The court further observed that "the statutory scheme was reasonably designed to obtain equality of tax burdens. ..."14 The United States Supreme Court upheld the action of the California Supreme Court by dismissing for want of a substantial federal question ${ }^{15}$ the appeals taken by the banks.

\footnotetext{
7 Baltantune, Californta Corporatton Laws ch. 20 (1932).

${ }^{8}$ Report of the California Tax Research Bureau (1933).

: 9.Rev. Stat. § 5219 (1875), 12 U.S.C. \& 548 (1958).

- 10 Section $4 a$ of the Bank and Corporation Franchise Tax Act (now CaL. Rev. \& Tax Code, $\$ \$ 23186,23186 a$ and 23186b). The 1933 amendments were the subject of a three part article by Professor Traynor and Frank M. Keesling, Recent Changes In The Bank And Corporation Franchise Tax Act, 21 CallF. L. Rev. 543 (1933), 22 Caltr. L. Rev. 499 (1934), 23 CALTF. L. REv. 51 (1934).

11 "Massachusetts and California appear to have found the fairest solution to this problem. ..." Howell, Special Problems in State Taxation of Bank Income, 9 NAT'x TAX J. 278, 281 (1956).

1255 Cal.,2d 407, 359 P.2d:625,-11 Cal. Rptr. 289 (1961). (Traynor; J. did:not participate in the consideration or decision of the case.)

$13 \mathrm{Id}$. at $414-15$.

$14 I d$. at $41 \%$.

16 Security First Nat'l Bk. v. Franchise Tax Bd., 368 U.S. 3 (1961).
} 
In 1933 the legislature also enacted the Retail Sales Tax Act, ${ }^{10}$ for which Traynor served as the chief draftsman and first administrator. Traynor also participated in the drafting of the Motor Vehicle Transportation License Tax Act, ${ }^{17}$ enacted in 1933, the Personal Income Tax Act ${ }^{18}$ and the Use Tax Act, ${ }^{19}$ enacted in 1935, and the Corporation Income Tax Act, ${ }^{20}$ the Private Car Tax Act, ${ }^{21}$ and the Use Fuel Tax Act, ${ }^{22}$ enacted in 1937.

All through the nineteen-thirties the then Professor Traynor executed with distinction a series of impressive responsibilities in taxation, serving various times as Legal Counsel to the Tax Research Bureau, Sales Tax Administrator, Consultant to the State Board of Equalization, Consulting Tax Expert for the United States Treasury Department and Consultant to the Attorney General of California. Some of these special assignments continued until he was appointed an Associate Justice of the Supreme Court of California in 1940.

Before his appointment to the Supreme Court, Chief Justice Traynor wrote extensively on tax subjects. The author remembers that lights burned late at night in Traynor's basement office in the old Boalt Hall, and, perhaps as recompense, his writings illuminate the field of state taxation. These articles attracted nationwide attention and have been praised for their analytical qualities. His skill in forecasting trends was noted in an article by Professor Thomas Reed Powell of Harvard, an astute analyst of United States Supreme Court opinions on state taxation. In "New Light on Gross Receipts Taxes,"23 Powell said the decision in McGoldrick v. Berwind-White Coal Mining Co.", "was one to be anticipated by careful readers of recent Supreme Court opinions. . . .22s and cited a Traynor article in which he had reviewed and summarized the Western Live Stock case and later ones: "There are strong indications that ... [the Supreme Court] will recognize outright the power of states not only to reach sales in interstate commerce directly rather than through taxes which are ostensibly upon use but also to make the retailer the taxpayer in form as well as in substance." "226

In the article referred to by Professor Powell, Professor Traynor

10 Stats. 1933, ch. 1020, pp. 2599.

17 Stats. 1933, ch. 339, p. 928.

18 Stats. 1935 , ch. 329, p. 1090.

19 Stats. 1935, ch. 361, p. 1297.

20 Stats. 1937, ch. 765 , p. 2184.

21 Stats. 1937 , ch. 283 , p. 621.

22 Stats. 1937, ch. 352 , p. 763.

23 Powell, New Light on Gross Receipts Taxes, 53 HARv, L. REv. 909, (1940).

24309 U.S. 33 (1940).

25 Powell, note 23 supra at 910.

26 Id. at $910 \mathrm{n.3}$. 
made a detailed analysis of then current United States Supreme Court opmions and summarized the trend:

For many years the Supreme Court has read into the commerce clause much that restricted state power to tax interstate commerce. As a result interstate commerce leaped and bounded across state lines in a comfortable freedom from many of the tax burdens laid upon local commerce and the time came when the latter found itself in need of protection against discriminatory taxation. The Court has been sensitive to this development for its recent decisions greatly liberalize the restrictive effect of earlier interpretations of the commerce clause upon state taxation of interstate commerce. ${ }^{27}$

II

EQUTTABIE DISTRIBUTION OF TAX BURDEN

There are many measures of a civilization; one is the way in which it collects and spends its revenue. Traynor devoted his imagination and energies toward realizing a just and efficient tax system in California. He was concerned with collection not merely in terms of enforcement but with particular emphasis upon an equitable distribution of the tax burden. We find this theme of equitable distribution of the tax burden constantly recurring through his work as legislative draftsman, legal scholar, and judge. ${ }^{28}$ There has been recognition among judges and scholars of how much his work contributed toward aclieving that goal. ${ }^{29}$ His preoccupation with that objective is well exemplified in an article he wrote supporting the constitutionality ${ }^{30}$ of the California Use Tax Act, ${ }^{31}$ following its enactment in 1935, and on much the same reasoning and authority contained in his article ${ }^{32}$ the United States Supreme Court soon thereafter uplield the validity of the Califorma use tax. ${ }^{33}$

As Deputy Attorney General, Chief Justice Traynor appeared as one of the counsel for the state on the brief in Felt \& Tarrant Manufacturing

27 Traynor, State Taxation and the Commerce Clause in the Supreme Court, 1938 Term, 28 CazTr. L. Rev. 168 (1940).

28 See, e.g., Traynor \& Surrey, New Roads Toward the Settlement of Federal Income, Estate and Gift Tax Controversies, 7 LAW \& Contearp. ProB. 336 (1940); Traynor, State Taxation of Trust Income, 22 IowA L. Rev. 268, 270-71 (1937); Analysis of the Bank and Corporation Franchise Tax Act 2, 3, 15, 34 (1933); Traynor, The California Use Tax, 24 Carre. L. Rev. 175, 176, 178 (1936).

29 Security-First Nat. Bk. v. Franchise Tax Bd., 55 Cal. 2d 407, 414-15, 417, 359 P.2d 625, 11 Cal. Rptr. 289, appeal dismissed, 368 U.S. 3 (1961). Howell, Special Problems

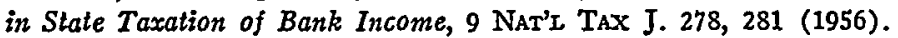

80 Traynor, The California Use Tax, 24 CaLrF. L. REv. 175 (1936).

81 Stats. 1935, ch. 361, p. 1297.

82 Traynor, The California Use Tax, 24 CaLrr. L. Rev. 175, 180 (1936).

83 So. Pacific Co. v. Gallagher, 306 U.S. 167 (1939) ; Pacific Tel. \& Tel. Co. v. Gallagher, 306 U.S. 182 (1939). 
Co. v. Gallagher, ${ }^{84}$ a leading case upholding the right of the state to require out-of-state retailers who maintained places of business in California to collect use tax from California customers and remit it to the state. His own words graphically express his concern with equality in taxation: "The expansion of governmental functions has intensified the dual problem of finding adequate public revenues and distributing the burden of taxation equitably among taxpayers according to their ability to pay. The revenue laws must be as delicately planned as the arrangement of cargo for the hold of a ship if they are to equilibrate the incidence of a variety of taxes. . ...335

There is abundant evidence of such delicate planning in the California tax system. The bank tax was designed to equalize the tax burdens of banks and other corporations $;^{36}$ the use tax to protect California retailers from discrimination in favor of out-of-state competitors; ${ }^{37}$ the corporation income tax to protect corporations engaged in intrastate commerce from discrimination in favor of corporations engaged exclusively in interstate commerce. ${ }^{38}$ Traynor was constantly on the alert to close loopholes that would permit some taxpayers to escape taxation at the expense of others. He concurred fully in the statement in the Report of the California Tax Research Bureau that: "Equitable tax apportionment is a matter of prime consideration in any study of methods for raising public revenues. Everyone is agreed that the burden of taxation ought to be fairly apportioned." 39

Summarizing the objective of the far-reaching overhaul of the California tax system in the nineteen-thirties, in whicl he played such a prominent role, he declared: "We were proud that we had carried through proposals designed to distribute the tax burden as equitably as possible. We wanted the new laws to work in the fairest possible manner and with the maximum possible efficiency. . .."

Given a broad scope of review, an appellate court can better supervise the uniform application of a revenue system. A court has this broad scope when reviewing questions of law. In his judicial work Chief Justice Traynor insists on a distinction between questions of fact and questions of law which fosters uniformity in the tax treatment of taxpayers who

34306 U.S. 62 (1939).

35 Traynor \& Surrey, supra note 28 , at 336 .

- ${ }^{86}$ See Security-First Nat. Bk. v. Franchise Tax Bd., 55 Cal. 2d 407, 416, 359 P 2d:625, 629, 11 Cal. Rptr. 289, 293 :(1961).

87 Traynor, The California Use Tax, 24 Canrr. L. Rev. 175, 178 (1936).

88 West Pub. Co. v. McColgan, 27 Cal. 2d 705, 710, 166 P.2d 861, 864 (1946). ’ .

39 Report of the CaI. TAX RESEARch BUREaU. 10. (1933).

40 Traynor, Quasi-Judicial:Reflections on Tax Administration, REvenUE ADMINISTRATION 1958, at 2 (published by National Association of Tax Administrators). 
are similarly situated." "What a taxpayer's activities are is a question of fact; whether such activities give rise to tax hability is a question of law depending on what the statute means and how it applies to the facts. . ...942

Chief Justice Traynor's persistent efforts to equalize the operation of California tax laws have contributed much to the overall success of the state's revenue system.

\section{III}

\section{ADMINISTRATION}

As the first administrator of the California sales tax, Traynor was entrusted with setting up the machinery and evolving the ground rules for the collection of this tax and for the guidance of some 200,000 retailers. He and Dixwell Pierce joined forces to create an administration that became known throughout the country as a model of efficiency, justice, and a remarkable combination of impartiality and courtesy to all taxpayers. Administrators in any field will find no less entertaining than enlightening his vivid account of the tumultuous problems of that time. ${ }^{43}$

In 1956 he reiterated the need for the best possible administration in tax agencies "wliose operations touch every single citizen all the time." He suggested that the greatest responsibility of the tax administrator may well be that of "encouraging and inaintaining the cooperation of all the taxpayers by his inpartial and conscientious administration," and by his taking the pains to explain to taxpayers the operation of the tax laws. ${ }^{48}$ In his words:

We might make a great advance in the settlement of tax controversies if we squarely accepted in practice what we cannot reasonably reject in theory-that the taxpayer and the administrator have a common interest in early settlement. The taxpayer should feel free at the outset to make full disclosure without fear of reprisal. The administrator with whom he deals should have the authority and the grace to yield forthwith and forthrightly when the fully disclosed facts bear out the taxpayer's contentions, whether the amount at stake be large or small. Moreover, if his own investgation discloses overpayments, he should take the initiative in securing prompt refund to the tax-

41 See Estate of Madison, 26 Cal. 2d 453, 456, 159 P.2d 630, 632 (1945); Pacific Pipeline Constr. Co. v. State Bd. of Equalization, 49 Cal. 2d 729, 736, 321 P.2d 729, 733-34 (1958). 42 California Motor Transp. Co. v, State Bd, of Equalization, 31 Cal. 2d 217, 228, 187 P.2d 745, 749 (1947) (dissenting opinion).

43 Traynor, supra note 40 , at 2.

44 Traynor, Tax Laws Deserve Sound Administration, Procesdings of ForTy-NinTH AnNual Conference of National Tax Assoctation 44 (1956).

45 Id. at 47 .

48 See Traynor, supra note 40 , at 2. 
payer. Actually, many administrators outspokenly advocate such a policy. .... .

He stressed that tax administrators have the key responsibility for the rational development of tax law..$^{48}$

IV

\section{PROCEDURE}

Chief Justice Traynor's understanding of the procedural as well as the substantive aspects of taxation is apparent in the various briefs in which he participated on behalf of the state ${ }^{40}$ as well as in the statutes he continued to draft throughout his early career. All of his work bears the marks of first-rate scholarship and lucid writing.

He became interested in the procedural and practical problems a state faces in attempting to collect its taxes from a taxpayer who has moved to another state. In cooperation with Professor James P. McBaine, his colleague at the University of Cahiforma School of Law, Traynor drafted a statute, modeled on nonresident motorists statutes, which was enacted by the legislature in 1939 as Section 1018 of the Code of Civil Procedure. This section made it possible to obtain a judgment in the California courts on the basis of substituted service, and hence made possible an action on the judgment in the state in which the delinquent taxpayer was then residing. ${ }^{50}$ Section 1018 has proved useful in the collection of taxes from nonresidents, and lias been helpful because the gradual erosion of the archaic rule that one state will not enforce the tax laws of another ${ }^{61}$ has been slow and erratic. ${ }^{52}$ Nearly thirty years

47 Traynor, supra note 44 , at 49.

$48 I d$. at 46.

48 People v. Skinner, 18 Cal. 2d 349, 115 P.2d 488 (1941); Holmes v. McColgan, 17 Cal. 2d 426, 110 P.2d 428 (1941); San Diego Trust \& Sav. Bank v. County of San Diego, 16 Cal. 2d 142, 105 P.2d 94 (1940); City Investments, Ltd. v. Johnson, 6 Cal. 2d 150, 56 P.2d 939 (1936); Standard Oil Co. of Cal. v. State Bd. of Equalization, 6 Cal. 2d 557, 59 P.2d 119 (1936); Pacific Elec. Ry. Co. v. Dep't of Motor Vehicles, 4 Cal. 2d 181, 48 P.2d 657 (1935); Fullerton Oil Co. v. Johnson, 2 Cal. 2d 162, 39 P.2d 796 (1934); Southern Cal. Tel. Co. v. County of Los Angeles, 45 Cal. App. 2d 111, 113 P.2d 773 (1941). 50 Suit on a judgment for taxes is not regarded as a suit to enforce the penal laws of another state. County of Milwaukee v. M. E. White Co., 296 U.S. 268 (1935). See Note, 49 HaRv. L. REv. 490 (1936); Note, 10 So. Car. L. Rev. 197 (1937).

51 See, e.g., Colorado v. Harbeck, 232 N.Y. 71, 133 N.E. 357 (1921); Moore v. Mitchell, 30 F.2d 600 (2d Cir. 1939). For an eloquent expression of the need that archaic concepts unresponsive to social realities be swept away, see Traynor, Law and Social Change in a Democratic Society, 1956 U. ILI. L.F. 230.

52 For example, enforceinent was granted in State ex rel. Oklahoma Tax Comm'n v. Rodgers, 238 Mo. App. 1115, 193 S.W.2d 919 (1946), but denied in City of Philadelphia v. Cohen, 11 N.Y.2d 401, 184 N.E.2d 167, cert. denied, 371 U.S. 934 (1962). See Comment, 16 Hastrngs L.J. 101, 104-05 (1964) for citation of additional cases reaching conflicting results. 
ago, Chief Justice Traynor pointed to the desirability of legislation in the various states which would provide for the reciprocal enforcement of tax laws of other states. ${ }^{53}$ Significant progress has occurred in this direction, particularly in recent years. ${ }^{54}$

There were other procedural problems that engaged the interest of the scholarly expert. In the late nineteen-thirties he precipitated a spirited controversy with a proposal for a new admimistrative and judicial procedure for federal income, estate and gift taxes. ${ }^{55}$ The views he set forth still make timely reading.

In 1937-38, as Consulting Tax Expert for the United States Treasury Department, Traynor was in charge of the administrative proposals for the Revenue Act of 1938. Among those that came to fruition was the notable section 820 (now Sections 1311-15 of the Internal Revenue Code). This section corrected an injustice that had recurred whenever the running of the statute of himitation on refunds and the statute of limitation on deficiencies did not coincide. ${ }^{56}$

In other procedural matters, Traynor had a leading part in drafting legislation $^{57}$ implementing the 1933 amendment of article XIII, section 14 of the California constitution, which provides for the assessment of public utility property by the State Board of Equalization. He also has analyzed in depth the problems of property tax collection, ${ }^{58}$ and has explored the subject of declaratory rulings in tax matters. ${ }^{.9}$

\section{$\mathrm{V}$}

\section{TAX OPINIONS}

For two years after he became a niember of the California Supreme Court, Chief Justice Traynor disquahified himself in all tax cases, and

53 Traynor, The California Use Tax, 24 CaLIF. L. Rev. 175, 182-83 (1936).

54 At least thirty-four states now have tax comity statutes. 25 STATE TAX REview No. 34, at 1 (CCH. Aug. 24, 1964); Comment, 16 Hasrongs L.J. 101, 109 (1964).

55 Traynor, Administrative and Judicial Procedure for Federal Income, Estate, and Gift Taxes-A Criticism and A Proposal, 38 Colons. L. REv. 1393 (1938). See also Traynor and Surrey, New Roads Toward the Settlement of Federal Income, Estate and Gift Tax Controversies, 7 LaW \& Contemp. Prob. 336 (1940).

56 Maguire, Surrey, \& Traynor, Section 820 of the Revenue Act of 1938, 48 YALE L.J. 509, 719 (1939).

57 Cax. Pol. Code $\$ \S 3663 a-3663$ d enacted by Stats. 1933, ch. 1045, p. 2687, and Stats. 1935, chs. 239, 260 and 529, at 919, 945, 1606 (now revised and codified in Car. REv. \& TAX CODE $\$ \S 751-892$ ).

68 Traynor, Model Real Property Tax Collection Law, 24 CaLIF. L. Rev. 98 (1935). Recently he confronted this problem in the context of what remedies are available to property taxpayers. His opinion in Star-Kist Foods, Inc. v. Quinn, 54 Cal. 2d 507, 354 P.2d 1, 6 Cal. Rptr. 545 (1960), held the taxpayer was not entitled to a writ of mandate as the remedy at law was adequate.

59 Traynor, Declaratory Rulings, 16 TAXES 195 (1938). 
thereafter disqualified himself in tax cases involving problems on which he had worked as Deputy Attorney General. In the course of his long judicial career, however, he has written various notable opinions on taxation, occasionally by way of dissent. Thus, in Rosemary Properties, Inc. v. McColgan ${ }^{60}$ involving a dividend deduction provision of the Bank and Corporation Franchise Tax Act, his dissent emphasized the legislative purpose of closing a tax loophole and promoting equality. Characteristically, he took exception to superficial analysis:

A comprehensive tax statute such as the Bank and Corporation Franchise Tax Act exemplifies intricate draftmanship; it evolves out of the painstaking dehiberations and studies not only of public officials but of others interested in tax legislation. Such a statute, wrought from a consideration of many conflicting interests, cannot long retain unity and coherence if one section or another is refabricated by the courts without regard for the structural whole. ... ${ }^{61}$

Chief Justice Traynor wrote the opinion in Fifth Street Building v. $M c$ Colgan, ${ }^{62}$ holding that a trustee in bankruptcy conducting the business of a corporation is subject to the franchise tax, and in Golden State Theatre and Realty Corp. v. Johnson, ${ }^{03}$ analyzing what constitutes "doing business" within the meaning of the Bank and Corporation Franchise Tax Act. He also wrote the landmark opinion upholding the validity of the California corporation income tax with respect to foreign corporations engaged exclusively in interstate commerce, West Publishing Co. v. $M c$ Colgan. ${ }^{64}$ The United States Supreme Court apparently was so favorably impressed with this opimion that it merely affirmed per curiam, ${ }^{65}$ citing some of the cases relied upon by Chief Justice Traynor in the opinion written for the California Supreme Court.

The corporation income tax was enacted in $1937 . .^{66}$ One of its purposes was to tax corporations that were deriving income from sources in California but were not subject to the franchise tax because they engaged exclusively in interstate commerce. The equalizing effect of the corporation income tax is described by Traynor in West Publishing: "Before the enactment of the Corporation Inconie Tax Act, foreign corporations engaged in interstate business within the state without being subject to a tax burden comparable to the franchise tax imposed on do-

6029 Cal. 2d 677, 117 P.2d 757 (1947).

61 Rosemary Properties, Inc. v. McColgan, 29 Cal. 2d 677, 700, 177 P.2d 757, 771 (1947) (dissenting opinion).

6219 Cal. 2d 143, 119 P.2d 729 (1941).

6321 Cal. $2 d$ 493, 133 P.2d 395 (1943).

6427 Cal. 2d 705, 166 P.2d 861 (1946).

65328 U.S. 823 (1946).

${ }^{66}$ Stats. 1937 , ch. 765 , p. 2184. 
mestic corporations and other foreign corporations competing in the same market. The Corporation Income Tax Act removed that discrimination." ${ }^{\prime 67}$ The opinion notes that "a tax does not discriminate against interstate commerce if other related taxes impose equal burdens on local commerce." 68

The West Publishing case serves as a significant interpretation not only of the commerce clause but also of the due process clause ${ }^{69}$ and of the statutory phrase "source of income." Insofar as the commerce clause is concerned, Chief Justice Traynor carefully explained the distinction between a tax on net income and a franchise tax ineasured by net income and the function served by each. The opinion also is a learned essay on the distinction betwen the subject and the ineasure of a tax. ${ }^{71}$

The distinctions noted by Chief Justice Traynor were confirmed and applied by the Supreme Court of the United States in later cases. Thus the Court, in Spector Motor Service v. O'Connor, ${ }^{72}$ held a state could not impose a franchise tax on a foreign corporation engaged exclusively in interstate commerce even if the tax were measured by apportioned net income.

Skeptics refused to believe that the West Publishing case established the validity of a state tax on apportioned net income of a foreign corporation engaged exclusively in interstate commerce. When, however, the question of such a tax again came before the United States Supreme Court, in Northwestern States Portland Cement Co. v. Minnesota, ${ }^{73}$ the West Publishing decision proved to be the pivotal case. "Any doubt as to the validity of our position here was entirely dispelled four years after Beeler, in a unanimous per curiam in West Publishing Co. v. $M c C o l g a n . . .{ }^{274}$ In his concurring opinion, Justice Harlan states: "I think that West squarely governs the two cases now before us. ${ }^{375}$

There are other significant Traynor opinions on taxation in which he resolved long standing controversies involving interpretations of the sales tax. In Pacific Pipeline Construction Co. v. State Board of Equaliza$t_{i o n}{ }^{76}$ Traynor held that a transfer of machinery and equipment from one related corporation to another, pursuant to a reorgamization and territorial division of business, was subject to sales tax. He also wrote the

${ }^{67} 27$ Cal. 2d at 710, 166 P.2d at 864.

68 Ibid.

60 Id. at 713,166 P.2d at 866 .

70 Id. at 712,166 P.2d at 863 .

$71 \mathrm{Id}$. at $708,166 \mathrm{P} .2 \mathrm{~d}$ at 863 .

72340 U.S. 602 (1951).

73358 U.S. 450 (1959).

74 Id. at 460 .

$75 \mathrm{Id}$. at 468.

7649 Cal. 2d 729, 321 P.2d 729 (1958). 
opinion in Decorative Carpets, Inc. v. State Board of Equalization, ${ }^{77}$ upholding a statutory requirement that if a retailer mistakenly collects excess sales tax reimbursement and pays the excess amount to the state, the Board of Equalization may require as a condition of refund to the retailer that the excess be returned to the customer from whom it was collected. The personal income tax ${ }^{78}$ and inheritance $\operatorname{tax}^{79}$ also have been the subject of opinions by Chief Justice Traynor.

In Martin Ship Service v. Los Angeles, ${ }^{80}$ Chief Justice Traynor did a remarkable job of analyzing a maze of United States Supreme Court precedents and extracting from them a guiding principle. This opinion, had it been that of the United States Supreme Court, would have resolved much of the confusion that has attended attempts to accommodate gross receipts taxes to the prohibitions of the commerce clause.

In addition to sales and gross receipts tax law, the Chief Justice has had a significant role in the development of the ad valorem property tax law of California, not only in his early career, ${ }^{81}$ but as a judge. He has written many opinions on both the procedural ${ }^{82}$ and substantive aspects of property taxation. In this latter area he has written opinions dealing with various principles of immunity from property taxation. ${ }^{83}$

In Roehm v. County of Orange, ${ }^{84}$ he held that liquor hicenses are immune froin property taxation, since they are intangibles not included in the definition of intangible personal property subject to taxation in Cahiforma.

Von Hamm-Young Co. v. San Francisco, ${ }^{85}$ afforded the Chief Justice

7758 Cal. 2d 252, 373 P.2d 637, 23 Cal. Rptr. 589 (1962).

78 Malmgren v. McColgan, 20 Cal. 2d 424, 126 P.2d 105 (1942).

70 Estate of Law, 50 Cal. 2d 345, 325 P.2d 449 (1958); Estate of Knapp, 37 Cal. 2d 827, 236 P.2d 372 (1951); Estate of Thurston, 36 Cal. 2d 207, 223 P.2d 12 (1950); Estate of Madison, 26 Cal. 2d 453; 159 P.2d 630 (1945); Estate of Newton, 35 Cal. 2d 830, 221 P.2d 952 (1950) (concurring opinion).

8034 Cal. 2d 793, 215 P.2d 24 (1950).

81 As deputy attorney general, Traynor represented the State of California in the property tax cases cited in note 49 , supra. See also Traynor, note 58, supra.

82 Mercury Herald Co. v. Moore, 22 Cal. 2d 269, 138 P.2d 673 (1943); Garvey v. Byram, 18 Cal. 2d 279, 115 P.2d 501 (1941); People v. County of Tulare, 45 Cal. 2d 317, 321, 289 P.2d 11, 13 (1955) (dissenting opimion); Hall v. Chamberlain, 31 Cal. 2d 673, 681, 192 P.2d 759, 764 (1948) (dissenting opinion); Universal Consol. Oil Co. v. Byram, 25 Cal. 2d 353, 364, 153 P.2d 746, 752 (1944) (concurring and dissenting opinion); Miller v. McKenna, 23 Cal. 2d 774, 785, 147 P.2d 531, 537 (1944) (dissenting opinion).

83 General Dynamics Corp. v. County of Los Angeles, 51 Cal. 2d 59, 330 P.2d 794 (1958) (possessory interests in personal property); Roehm v. County of Orange, 32 Cal. $2 \mathrm{~d} 280,196$ P.2d 550 (1948) (hquor hicenses); Von Hamm-Young Co. v. City and County of San Francisco, 29 Cal. 2d 798, 178 P.2d 745 (1947) (goods in transit); Ross v. City of Long Beach, 24 Cal. 2d 258, 148 P.2d 649 (1944) (school property).

8432 Cal. 2d 280, 196 P.2d 550 (1948).

8529 Cal. 2d 798, 178 P.2d 745 (1947). 
an occasion to write an illuminating summary of tax law concerning the immunity of "goods in transit." At issue was whether merchandise temporarily stored in warehouses in San Francisco awaiting shipping space to Hawaii during war time shortage of such space was subject to property taxation. Sonie of the inerchandise had originated out of state, some had come from points in California outside San Francisco, and some had been purchased in San Francisco. Accommodating war time exigencies, Traynor held that the temporary storage in San Francisco did not constitute a break in the interstate movenient, and that all of the nuerchandise was protected by the commerce clause from local property taxation.

In two cases, ${ }^{8 B}$ however, whicl involved the question whether Cahfornia had the power, with respect to the due process and commerce clauses, to tax vehicles (aircraft) engaged in interstate and foreign commerce, Chief Justice Traynor dissented from the majority opinions which granted tax immunity. ${ }^{87}$ In each of these cases he would have upheld the power of the state to levy the property tax in question. In one of the dissents he explored the relatively undeveloped area of "commercial domicile," its meaning and effect. ${ }^{88}$

In a case involving the taxation of intangible property, Timm Aircraft Corp. v. Byram, ${ }^{80}$ Chief Justice Traynor's opinion held taxable as a solvent credit $t^{00}$ a government contractor's special bank deposit of funds advanced to it by the federal government.

Chief Justice Traynor has written opinions of major significance concerning property taxation of possessory interests. His opinion in Forster Shipbuilding Co. v. County of Los Angeles, ${ }^{91}$ clarified the classification of property in holding that possessory interests in land, including leasehold interests in tax-exempt land, are real property, not personal property, for property tax purposes. ${ }^{92}$

Some of Traynor's other opinions in this area define what possessory interests in property are taxable and establish basic principles as to how taxable possessory interests are to be valued. In General Dynamics Corp. v. County of Los Angeles, ${ }^{03}$ he lield that a possessory interest in personal

${ }^{86}$ Scandinavian Airlines Sys., Inc. v. County of Los Angeles, 56 Cal. 2d 11, 363 P.2d 25, 14 Cal. Rptr. 25 (1961), cert. denied, 368 U.S. 899 (1961); Flying Tiger Line, Inc. v. County of Los Angeles, 51 Cal. 2d 314, 333 P.2d 323 (1958), cert. denied, 359 U.S. 1001 (1959).

8756 Cal. 2d 11, 43, 363 P.2d 25, 44, 14 Cal. Rptr. 25, 44, (1961); 51 Cal. 2d 314, 327, 333 P.2d 323, 331 (1958).

88 I Cal. 2d 314, 328 n.1, 333 P.2d 323, 331 (1961) (dissenting opinion).

8034 Cal. 2d 632, 213 P.2d 715 (1950).

oo See Car. Rev. Tax. Code $\$ 113$.

9154 Cal. 2d 450, 353 P.2d 736, 6 Cal. Rptr. 24 (1960).

82 Id. at 456,353 P.2d at 739, 6 Cal. Rptr. at 27.

9351 Cal. 2d 59, 330 P.2d 794 (1958). 
property is not taxable since the legislature for tax purposes has not defined personal property to include a right to its possession as it has real property.

In dealing with the taxation of possessory interests in real property, the Chief Justice has greatly influenced the law on valuation. With respect to evaluating the possessory interests of lessees of tax exempt real property, the California Supreme Court in L.W. Blinn Co. v. County of Los Angeles, ${ }^{94}$ had held that when such interests are evaluated by the capitalization of incoine method, deductions should be made from gross income for rentals to becoine due under the lease and for amortization of the cost of improvements by the lessee that would revert to the lessor. Chief Justice Traynor disagreed with this analysis. He wrote the opinion for the unanimous court in De Luz Homes, Inc. v. County of San Diego, ${ }^{90}$ overruling the Blinn case and holding that under the capitalization of income inethod there can be no deductions for rent, amortization, or payments of principal or interest on the lessee's mortgage debt. ${ }^{96}$ In Texas Co. v. County of Los Angeles, ${ }^{27}$ he pointed out that in the application of the rule of the De Luz case, no distinction should be drawn between rent paid and rent to be paid. ${ }^{98}$

In the course of the De Luz opmion, the definition of "full cash value" referred to in Section 110 of the California Revenue and Taxation Code was clarified as providing "for an assessment at the price that property would bring to its owner if it were offered for sale on an open market under conditions in which neither buyer nor seller could take advantage of the exigencies of the other. . . " standard frequently referred to in subsequent opinions and legal writings. ${ }^{100}$

His opinion in Forster Shipbuilding Co. v. County of Los Angeles, ${ }^{101}$

94 216 Cal. 474, 14 P.2d 516 (1932).

9545 Cal. $2 \mathrm{~d} 546,290$ P.2d 544 (1955).

${ }^{96}$ In addition to the $D e$ Luz Homes opinion, Justice Traynor wrote the opinions in 'the related cases of Fairfield Gardens, Inc. v. County of Solano, 45 Cal. 2d 575, 290 P.2d 562 (1955), Victor Valley Housing Corp. v. County of San Bernardino, 45 Cal. 2d 580, 290 P.2d 565 (1955), and El Toro Dev. Co., Inc. v. County of Orange, 45 Cal. 2d 586, 290 P.2d 569 (1955).

9752 Cal. 2d 55, 338 P.2d 440 (1959).

98 Id. at $61,338 \mathrm{P} .2 \mathrm{~d}$ at 442 .

0945 Cal. 2 d $546,561-62,290$ P.2d 544, 554!

100 Michael Todd Co. v. County of Los Angeles, 57 Cal. 2d 684, 694, 370 P.2d 340, 342, 21 Cal. Rptr. 604, 611 (1962); County of Tuolumne v. State Bd. of Equalization, 206 Cal. App. 2d 352, 366, 24 Cal. Rptr. 113, 122 (1962) ; A. F. Gilmore Co. v. County of Los Angeles, 186 Cal. App. 2d 471, 475, 9 Cal. Rptr. 67, 71 (1960); 44 Ops. Cal. Att'y Gen. 24, 25 (1964); 30 Ops. Cal. Att'y Gen. 246 (1957); Note, 12 Stan. L. Rev: 638, 641 n.19 (1960).

10154 Cal. 2d 450, 353 P.2d 736, 6 Cal. Rptr. 24 (1960). 
concerned a statute passed by the legislature to give relief to lessees of tax-exempt property with respect to leases entered into prior to the decision in the $D e L u z$ case. The statute thus provided, in effect, that possessory interests created prior to the $D e L u z$ decision should be valued under the rule of the overruled Blinn case. The statute did not purport to change the rule of the $D e L u z$ case as to possessory interests created after the decision in that case. The validity of the statute was sustained as a reasonable exercise of the legislature's power "to mitigate hardships caused by the overruling of established law. . . ."102 It was pointed out that "Since adjustments in rentals can be made in leases created, extended, or renewed after the $D e L u z$ case, such leases are properly excluded from the operation of the section. ..."103

In a dissent involving the motor vehicle transportation hicense $\operatorname{tax}^{104}$ Chief Justice Traynor evinced his concern for substance as against such artificialities as the method of bookkeeping employed by the taxpayer. ${ }^{105}$ In his view the majority opinion gave the taxpayer "an unwarranted competitive advantage over others engaged in the same activities," and defeated the uniform operation of the statute. ${ }^{107}$

\section{CONCLUSION}

We are alert in the mineteen-sixties to the value of education. The statistics-minded translate its monetary value in terms of the rewards to the educated or the return they make to the community. Chief Justice Traynor received all his higher education at the University of Cahifornia. The state took a risk on the young, unknown student whose only assets were a sterling mind and sterling character. We can now estimate the return he has made to the State of California on the investment in his education.

His inaginative and analytical genius for taxation has engendered a boundless wealth of revenues for the state. In sum, the state has reaped millions for every dollar invested in his education. There are returns of still greater import, however, that cannot be measured in monetary terms. Chief Justice Traynor, now known througlout the world as one of the great jurists of our time, continues to set an example par excellence of an educated unan of law. Scholar, teacher, draftsman, admmistrator, writer, jurist-in each of these capacities his work bears the hallmark of ex-

102 Id. at 459,353 P.2d at 740, 6 Cal. Rptr. at 28.

103 Id. at 460,353 P.2d at 741, 6 Cal. Rptr. at 29.

104 CaL. Rev. \& TAX. Code \$ 9651.

105 California Motor Transp. Co. v. State Bd. of Equalization, 31 Cal. 2d 217, 224,

187 P.2d 745, 749 (1947) (dissenting opinion).

$106 \mathrm{Id}$. at $224,187 \mathrm{P} .2 \mathrm{~d}$ at 752 .

107 Id. at 229,187 P.2d at 752 . 
cellence. What counts most, and is yet beyond counting, is that throughout the country young and unknown law students are coming upon the Traynor opinions in taxation, as in other fields, with a sense of discovery, with a quickened understanding of their obligations to use their education to noble purpose. 